\title{
Social entrepreneurship in the Republic of Croatia: what do we know and what are the future potentials and benefits?
}

\begin{abstract}
Social entrepreneurship combines various activities undertaken by an entrepreneur with the main aim of combating social problems in the society whilst creating positive social values. Its activities are addressed towards helping those vulnerable people who need help the most, helping marginalised interested stakeholders and people with disabilities. The main aim of social entrepreneurship is not in terms of profit generation and the monetary measurement of results achieved. Rather, results are measured in terms of the number of new jobs generated, the number of people with disabilities who are included in entrepreneurial activities and the development of society. The aim of this article is to highlight the benefits of social enterprises and potentially to stimulate enthusiast in Serbia to start a social business for the benefits of all, drawn from original research. The results show that the civil sector has spawned social enterprises that will surely find their space in the economic sector.
\end{abstract}

Keywords: social entrepreneurship, social enterprises, social value, organisational form, co-operative associations, civil society, poverty, social need, employment, integration, disability, government support

\section{Introduction}

For almost one hundred years, there have been initiatives struggling to position social entrepreneurship in the context of the market economy. Today, this is a growing movement around the world due to its favourable combination of activities, and various definitions of social entrepreneurship and social entrepreneurs exist as a result of the growing popularity of the concept. Social entrepreneurship uses market-based methodologies in seeking to resolve some of the prevalent social and environmental issues. However, the main focus is not in the pure profit purpose of an enterprise (i.e. the maximisation of financial returns for shareholders), but rather on the creation of varieties of social transformation. In this context, the main aim of social enterprises is to create a distinctive social value and to direct economic gains to those beneficiaries who are the direct targets of the activity. They may be reached either by re-investing the profits of business activity in tackling social issues in the community or otherwise by involving those at the bottom of the pyramid in the activity of the social enterprise.

Social entrepreneurship combines market-based forms of organisation (the creation of economic gains) with charity-based forms, in which resources are acquired by promising potential donors indirect social returns (Battilana and Dorado, 2010). Wealth 
accumulation is not a priority - revenues beyond costs are reinvested in the enterprise in order to fund expansion (Hartigan, 2006: 45). There are those proponents who position social entrepreneurship where markets have failed to conduct their main role.

The notion of trading for a social purpose is at the core of social entrepreneurship, requiring that social entrepreneurs identify and exploit market opportunities, and assemble the necessary resources, in order to develop products and/or services that allow them to generate 'entrepreneurial profit' for a given social project (Tracey and Jarvis 2007: 671).

Social business is about how social entrepreneurs work and what they do with the profit they generate. Social entrepreneurs employ people who otherwise would be left out; they reinvest profits in projects for the benefit of the community; they work significantly in areas of environmental protection and sustainability; they work to provide social services for the most vulnerable; etc. Various organisational forms of social enterprises can be found among many different sectors. These enterprises offer many advantages over standard businesses, government companies or non-profit organisations. This is why they may be considered as the 'missing middle'.

The aim of this paper is to cast some light on the theoretical concept of social entrepreneurship through a review of the literature on the topic, covering the latest points in the development of social entrepreneurship as well as to present the benefits of such enterprises. The case of the Republic of Croatia is presented drawn from webbased research (based on the Pomakonline database of social enterprises in Croatia), as well as interviews conducted in March and April 2013 in order to reveal the stage which the development of social entrepreneurship has reached, within which sectors social enterprises currently exist and with what activities the existing enterprises are involved. The future potential of various organisational forms of social enterprises in Croatia are also presented, bearing in mind the currently unfavourable macroeconomic conditions in the Republic of Croatia. On the basis of this empirical research, the main purpose of this paper has been achieved.

\section{What is social entrepreneurship?}

The focus of this section is on revealing the main characteristics of social entrepreneurs and social enterprises, as well as the activities on which social entrepreneurship is focused, drawn from a review of the available literature.

\section{Social entrepreneurs - ordinary people, enthusiasts and moral agents}

Social entrepreneurs are those individuals that have a great potential and affinity towards innovations, innovative solutions and methods. They are not scared of taking responsibility in terms of developing their ideas and running a social business despite the high uncertainty and risk that these activities pose. However, they differ widely from standard entrepreneurs due to their willingness and commitment to social issues. Their ideas are focused on the user-friendly, the understandable and the ethical, and they engage widespread support in order to maximise the number of local people that will stand up, seize the idea and implementing it. Every leading social entrepreneur is a mass recruiter of local change-makers. They have the characteristics of successful 
entrepreneurs, such as tenacity in the face of failure (Barringer, 2010: 34). They are not motivated by generating high returns on investments or of profiting from their business activity. Their ideas are transformed into social innovations benefiting the community at large, particularly those poor and vulnerable who are at the bottom of the pyramid. Hence, the array of innovations they create have the primary intention of creating a better society through social innovation. Social innovations are channelled to those who need them most, not discounting the general welfare benefits also available to the local and regional community. Ashoka (2012) sees them as ambitious and persistent people, tackling major social issues and offering new ideas for wide-scale change. Social entrepreneurs are something like change agents for society, seizing opportunities that others miss; in improving systems, inventing new approaches and creating solutions to change society for the better, they come up with new solutions to social problems and then implement them on a large scale. A social entrepreneur is similar to a business entrepreneur: he builds strong and sustainable organisations which are either set up as not-for-profit organisations or as conventional companies (Schwab Foundation for Social Entrepreneurship, 2012). Social entrepreneurs are individuals or private organisations that take the initiative of identifying and addressing important social problems in their communities (Korosec and Berman, 2006: 448-449). The Schwab Foundation (2012) sees social entrepreneurs as those who dedicate their lives to social improvement.

There are various fields in which social entrepreneurs act: from education, to health and safety systems, environmental protection, enterprise development, etc. Social entrepreneurs have all the characteristics set out in Table 1 that make them a leader or pragmatic visionary.

\section{Table 1 - Characteristics of social entrepreneurs}

\begin{tabular}{|l|l|}
\hline Are innovative & $\begin{array}{l}\text { Achieve large scale, systemic and sustainable social change } \\
\text { through a new invention, a different approach, a more } \\
\text { rigorous application of known technologies or strategies, or } \\
\text { a combination of these. Innovate by finding a new product, a } \\
\text { new service or a new approach to a social problem }\end{array}$ \\
\hline Act sustainably & $\begin{array}{l}\text { Focus first and foremost on social and/or ecological value } \\
\text { creation and try to optimise the creation of financial value }\end{array}$ \\
\hline Always try to reach out & $\begin{array}{l}\text { Continuously refine and adapt approaches in response to } \\
\text { feedback }\end{array}$ \\
\hline Have a social impact & $\begin{array}{l}\text { Combine the characteristics of Richard Branson and Mother } \\
\text { Teresa }\end{array}$ \\
\hline $\begin{array}{l}\text { Have an unwavering belief in } \\
\text { people }\end{array}$ & $\begin{array}{l}\text { Believe in the innate capacity of all people to contribute } \\
\text { meaningfully to economic and social development and have } \\
\text { a driving passion to make that happen }\end{array}$ \\
\hline $\begin{array}{l}\text { Have a practical but innovative } \\
\text { stance to a social problem }\end{array}$ & $\begin{array}{l}\text { Often use market principles and forces, coupled with dogged } \\
\text { determination. This allows them to break away from the } \\
\text { constraints imposed by ideology or field of discipline, and } \\
\text { pushes them to take risks that others would not }\end{array}$ \\
\hline
\end{tabular}




\begin{tabular}{|l|l|}
\hline $\begin{array}{l}\text { Have a zeal to measure and } \\
\text { monitor impact of decisions }\end{array}$ & $\begin{array}{l}\text { Entrepreneurs have high standards, particularly in relation to } \\
\text { their own organisation's efforts and in response to the } \\
\text { communities with which they engage. Data, both quantitative } \\
\text { and qualitative, are their key tools, guiding continuous } \\
\text { feedback and improvement }\end{array}$ \\
\hline Have a healthy impatience & $\begin{array}{l}\text { Social entrepreneurs cannot sit back and wait for change to } \\
\text { happen - they are change drivers }\end{array}$ \\
\hline
\end{tabular}

Source: authors' adaptation according to: The Schwab Foundation for Social Entrepreneurship

Social entrepreneurs are also (Skoll World Forum, 2012):

- ambitious - they tackle major social issues, from increasing the college enrolment rate of low-income students to fighting poverty; they also operate in all kinds of organisations: innovative non-profit ones, social purpose ventures and hybrid organisations

- mission-driven - they generate social value, not wealth. Wealth creation may be part of the process, but it is not an end in itself because promoting systemic social change is the real objective

- strategic - they see and act upon what others miss: spot opportunities to improve systems, create solutions and invent new approaches that create social value

- resourceful-social entrepreneurs operate within a social context in contrast to the rest of the business world, they have limited access to capital and traditional market support systems so social entrepreneurs must be skilled at mobilising human, financial and political resources

- results-oriented - social entrepreneurs are driven to produce measurable returns and these results transform existing realities, open up new pathways for the marginalised and disadvantaged, and unlock society's potential to effect social change.

\section{Social entrepreneurship and social enterprise}

The activities that are taken and the processes adopted within an organisation that has a common purpose - the creation of social value and social transformation - have found a favourable and common ground in social entrepreneurship. These processes may be interrupted by various obstacles during the product life-cycle; however, the main point is that social entrepreneurs continue to seek to realise their goals until the ultimate benefit and social value is reached. So, giving up is something that is rarely practised. The emphasis is placed on those vulnerable, marginalised and poor, whether in the local or regional community. Hence, activities are not limited to these interest groups but target also the community at large due its mission of bringing positive social changes in the environment and in the society in which examples of social entrepreneurship operate.

Social entrepreneurship encompasses the activities and processes undertaken to discover, define and exploit opportunities in order to enhance social wealth by creating new ventures or managing existing organisations in an innovative manner (Zahra et al, 2009: 5). It is a set of institutional practices combining the pursuit of financial objectives with the pursuit and promotion of substantive and terminal values (Cho, 
2006: 36). Financial objectives are reached with the purpose of reinvesting money for the social benefit of all, or for the creation of significant levels of social value.

The Schwab Foundation (2012) defines social entrepreneurship as a term that captures a unique approach to economic and social problems, an approach that cuts across sectors and disciplines, being grounded in certain values and processes that are common to each social entrepreneur independent of whether his/her area of focus has been education, health, welfare reform, human rights, workers' rights, environment, economic development, agriculture, etc., or whether the organisations they set up are non-profit or for-profit entities. Social entrepreneurship consists of any innovative initiative to help people. The initiative may be economic or non-economic, for profit or not-forprofit (Yunus, 2008: 32). Following this, Austin et al. (2006: 2) define social entrepreneurship as an innovative, social value-creating activity that can occur within or across the non-profit, business or government sectors.

That there is a strong correlation between motivation, ethics, human strength, willingness to change the world for the better and social entrepreneurship is unequivocal. Probably, there are other motivators as well. Miller et al. (2012) comment, however, that compassion can be set aside as one of the emotional motivators for social entrepreneurship.

Social entrepreneurs manage social enterprises. Social Enterprise UK (2012) regards social enterprises as businesses that seek to change the world. Social enterprises are accountable and transparent enterprises, with the clear social mission of reinvesting the majority of their income towards the achievement of their particular social purpose and for the benefit of the people who need to overcome social problems or for that of the society in which they operate.

Social enterprises are businesses that trade to tackle social problems and improve communities, people's life chances or the environment. They make their money from selling goods and services on the open market but reinvest profits back in the business or the local community so that, when they profit, society profits (Social Enterprise UK, 2012). However, a social enterprise should not be perceived only as an organisation which is engaged in selling goods and services on the open market, but the definition should also encompass non-profit organisations providing services for the community.

Consequently, various forms of social enterprise exist. 'Social enterprise' is a collective term for a range of organisations that trade for a social purpose. They adopt one of a variety of different legal formats, but have in common the principles of pursuing business-led solutions to achieve their social aims as well as the re-investment of surplus for the benefit of the community. Their objectives focus on socially-desired, nonfinancial goals, while their outcomes are the non-financial measures of implied demand for and supply of services (Haugh, 2006: 5). The particular organisational form is something which should reflect a strategic decision about the best advance which can be made as regards the social issue at hand.

Figure 1 below presents the different organisational models that social enterprises can undertake. 


\section{Figure 1 - Organisation models}

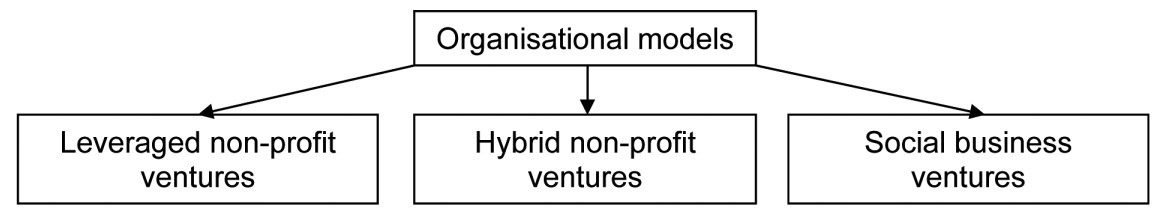

Source: Authors' adaptation according to: Schwab Foundation for Social Entrepreneurship,

\section{Leveraged non-profit ventures}

These are non-profit organisations which drive the adoption of an innovation that addresses a market or government failure. The entrepreneur engages a cross-section of society, including private and public organisations, to drive forward the innovation through a multiplier effect. They continuously depend on outside philanthropic funding, but their longer-term sustainability is often enhanced given that the partners have a vested interest in the continuation of the venture.

\section{Hybrid non-profit ventures}

These are non-profit organisations which include some degree of cost-recovery through the sale of goods and services to a cross-section of institutions, public and private. They may also target population groups. The entrepreneur may set up several legal entities to accommodate income earning and charitable expenditure within an optimal structure. Other sources of funding must be mobilised from the public and/or philanthropic sectors in order to be able to sustain transformation activities in full and address the needs of often poor or marginalised clients. Such funds can be in the form of grants or loans, and even quasi-equity.

\section{Social business ventures}

These are for-profit entities or businesses aiming to provide a social or environmental product or service. Ideally, profits are generated, but the main aim is not to maximise financial returns for shareholders but to grow the social venture and reach more people in need. Wealth accumulation is not a priority and profits are reinvested in the enterprise to fund expansion. The entrepreneur of a social business venture seeks investors who are interested in combining financial and social returns on their investments.

The Social Enterprise Alliance (2012) sees social enterprise as the 'missing middle' sector, as set out in Figure 2: 
Figure 2 - The 'missing middle'

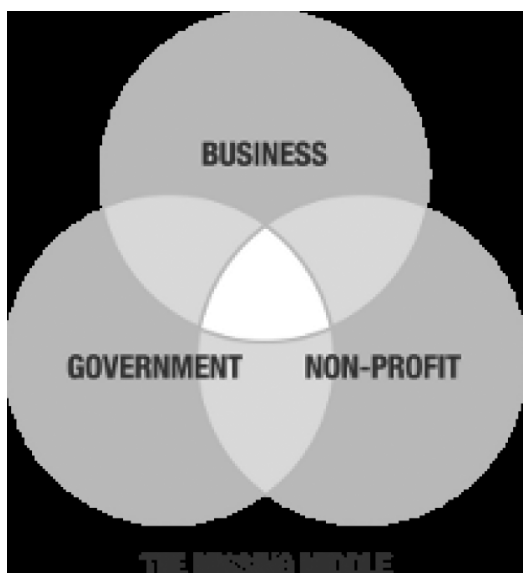

The 'missing middle' sector stands for the enterprise which:

1. addresses social concerns more efficiently than the government

2. does so more sustainably and creatively than the non-profit sector

3. and also more generously than business.

The authors of this article agree that the best model of social enterprise is the one which is self-sustaining, using market methods to achieve its goals with highly effective methods of meeting social needs. However, other forms of social enterprise are very valuable for the development of democratic society.

Social enterprise business models are equally diverse, including: retail, service and manufacturing businesses; contracted providers of social and human services; feebased consulting and research services; community development and financing operations; food service and catering operations; arts organisations; and even technology enterprises (Social Enterprise Alliance, 2012).

The following section presents the results of our research and makes some proposals as regards the future development of social enterprises in Croatia.

\section{Social entrepreneurship in the Republic of Croatia}

\section{Methodology}

To get a holistic picture of the current state of social business in Croatia, the authors conducted web research and held a direct-contact interview with an employee of the Foundation for Partnership and Civil Society Development in Istria. The web research was based on the criteria of social enterprises, as collected within the Pomakonline database of social enterprises. ${ }^{1}$ Pomakonline is the only initiative collecting the projects of social businesses in Croatia. It is an online magazine for social development, de- 
signed by Slap - Association for Creative Development, and it has been produced with the financial assistance of the European Union.

The direct interview enabled the authors not only to gain insights into the activities that foundations run, but also revealed some of the main obstacles to running a business of that kind which later enabled them to provide some proposals for the future development of social enterprises in Croatia.

\section{Research results}

In Croatia, social entrepreneurship is still highly under-developed and not even recognised although social enterprises have been operating, both in Europe and in the rest of the world, for more than a century. The main types of non-profit organisation in Croatia are: associations, co-operatives and foundations. Nevertheless, there are enthusiasts from the civil and the public sectors who have publicly advocated social entrepreneurship by other institutions but also for all interested citizens. These are mainly those enthusiasts which have formed varieties of co-operatives, foundations and social associations throughout Croatia. A pure social enterprise (one that is for profit), which produces goods and services with the aim of selling them on the market and reinvesting the profit gained, is rarely found in such a form because the majority of enterprises are formed as non-profit ones.

In today's situation, in a country with more than 1.3 million people, or $32.7 \%$ of the total population, who live in poverty, any strengthening of the capacity to develop social enterprises would be more than just welcomed. The Republic of Croatia covers an area of 87.6 square $\mathrm{km}$ and has 4.3 million inhabitants, of which $1.7 \mathrm{~m}$ may be considered as the active population. The unemployment rate for March 2013 was $21.6 \%$, while the employment rate was just $57 \%$. Compared with the EU, where the employment rate is $75 \%$, this is 18 percentage points lower. GDP (at current prices) is $\$ 56.4$ bn, whilst GDP per capita is $\$ 13172$. Compared to 2011, GDP growth is negative, at $-2 \%$, as is industrial production which was $5.5 \%$ lower than in 2011 (Croatian Chamber of Commerce, 2013).

Social entrepreneurship is mostly applied by companies which are non-profit and trying to help the local community, or a specific target group, through a social enterprise established for the purposes of the employment, rehabilitation and social integration of service users (those who are vulnerable and those in need of social assistance). It helps to resolve many social and economic problems through various associations and cooperatives. According to the Pomakonline database of social enterprises, there are: three social enterprises formed as limited liability companies, ( 1 of which is not yet operating), 28 associations and four co-operatives.

This means that, all together, there are 35 social enterprises in Croatia. All the social enterprises listed below have their own website, where they publish various information on the activities they run, push forward the transparency of their work and inform the audience of the mission, vision and main aims of their business. Some of the websites are really very informative, very clear and designed in contemporary fashion. However, there are some websites where there is an obvious lack of creativity and even some where the financial reporting is still not very transparent bearing in mind that the ma- 
jority have been financed by external funds (government, local and regional authorities) or by pure philanthropy.

Table 2 as follows gives a list and brief description of the work of some selected and active social enterprises in Croatia that have achieved numerous awards in the field of social entrepreneurship.

\section{Table 2 - The most well-known social enterprises in the Republic of Croatia}

\begin{tabular}{|c|c|}
\hline $\begin{array}{l}\text { Autonomous centre - ACT } \\
\text { Çakovec }\end{array}$ & $\begin{array}{l}\text { Centre for the improvement of the community by informing, } \\
\text { educating and counselling people }\end{array}$ \\
\hline ACT Printlab & $\begin{array}{l}\text { A company engaged in the development of design, marketing, } \\
\text { publishing and computer activities }\end{array}$ \\
\hline ACT Konto & $\begin{array}{l}\text { A service for accounting and auditing activities, tax consulting } \\
\text { and non-profit organisations }\end{array}$ \\
\hline $\begin{array}{l}\text { Social Co-operative Humana } \\
\text { Nova }\end{array}$ & $\begin{array}{l}\text { A non-profit co-operative that employs people with disabilities in } \\
\text { the manufacture and sale of eco-textile products }\end{array}$ \\
\hline $\begin{array}{l}\text { Rodin let d.o.o. - Roda } \\
\text { Association }\end{array}$ & $\begin{array}{l}\text { An organisation that is engaged in producing and promoting the } \\
\text { use of cloth nappies in the community }\end{array}$ \\
\hline $\begin{array}{l}\text { Association for Young } \\
\text { People Alfa Albona }\end{array}$ & $\begin{array}{l}\text { Encourages young people to communicate, create, volunteer and } \\
\text { be independent }\end{array}$ \\
\hline Zvono Association & $\begin{array}{l}\text { Croatian Association of Class Teachers (in elementary schools), } \\
\text { which produces and sells local products (souvenirs, herbs, etc.) in } \\
\text { the region }\end{array}$ \\
\hline Kamensko Association & $\begin{array}{l}\text { A non-profit organisation that helps unemployed women to equip } \\
\text { hemselves to work through cutting, sewing courses, etc. }\end{array}$ \\
\hline Baranja Association & $\begin{array}{l}\text { A non-profit association which promotes community develop- } \\
\text { ment and the application of information technology in the same }\end{array}$ \\
\hline AKD Mungos Ltd. & $\begin{array}{l}\text { A non-profit trade association that conducts de-mining activities } \\
\text { across Croatia for the benefit of the whole society }\end{array}$ \\
\hline $\begin{array}{l}\text { Agricultural Co-operative } \\
\text { Vodnjan-Dignano }\end{array}$ & $\begin{array}{l}\text { A co-operative established in order to improve agriculture in } \\
\text { Vodnjan with emphasis on olive growing and production }\end{array}$ \\
\hline $\begin{array}{l}\text { Co-operative of the } \\
\text { Association Koka hrvatica }\end{array}$ & $\begin{array}{l}\text { A non-profit co-operative in Virovitičko-Podravska County } \\
\text { dealing with the breeding of indigenous breeds of Croatian hens }\end{array}$ \\
\hline $\begin{array}{l}\text { Social Service Co-operative } \\
\text { Martinov plašt }\end{array}$ & $\begin{array}{l}\text { A voluntary social society which, with various activities, seeks to } \\
\text { create a sense of fellowship (communion) between vulnerable } \\
\text { groups of society }\end{array}$ \\
\hline $\begin{array}{l}\text { Co-operative on Energetics } \\
\text { Island of Krk }\end{array}$ & $\begin{array}{l}\text { A co-operative that provides community access to forms of } \\
\text { renewable energy and energy efficiency information }\end{array}$ \\
\hline $\begin{array}{l}\text { Social Association of } \\
\text { Business Women Krug }\end{array}$ & $\begin{array}{l}\text { Association of Business Women in Croatia, which aims to } \\
\text { strengthen the position of women in business in the community }\end{array}$ \\
\hline e.glas Rijeka & $\begin{array}{l}\text { A limited liability company producing systems that allow users } \\
\text { to use voice commands }\end{array}$ \\
\hline
\end{tabular}

Source: Authors' research 
It is important to underline that some of these encompass government initiatives which should be nourished. With the end of the war, the government of the Republic of Croatia established the Mungos association in 1996 as a sort of hybrid non-profit venture. The establishment of Mungos effected protection for the entire society, through the saving of lives by removing mines and facilitating the emergence of new arable land, etc. The company is primarily funded by donations and funds from the European Union, while one part is funded by the export of services by Mungos. Mungos, as a social enterprise, must increase the effectiveness and efficiency of its operations and is constantly investing in the education and training of its employees (both physically and through modern machinery and technology-operating activities) so as to enable them to perform quality humanitarian de-mining on a daily basis.

There are regional and local authorities which have also supported initiatives towards establishing a certain form of social enterprise. In particular, the city of Vodnjan (Dignano in Italian), in Istria, together with the Agrotourist Association, formed the Agricultural Co-operative Vodnjan-Dignano to enhance agriculture in Vodnjan, focusing on olive growing and processing, within which members strive to reach the market together, thus offering lower prices for their traditional products. The profits gained are re-invested in production. A form of social enterprise, this organisation can also be categorised as a hybrid non-profit venture.

Only one social enterprise can possibly be distinguished as one that is for-profit e.glas from Rijeka, which produces electronic systems that allows users to utilise voice commands to control their homes.

We might also underline the existence of the Foundation for Partnership and Civil Society Development as a leveraged non-profit venture. This is a non-governmental and non-profit organisation whose mission is to promote international co-operation, philanthropy, volunteerism and the overall development of democratic society, paying particular attention to the continuing improvement of life in local communities. It has three main functions:

1. information - it provides important information about civil society, i.e. information on how to act, who to present a project idea to or how to write a good project for the EU

2. finance - it invites tenders and publishes them on its website. All civil society organisations are invited to send project proposals. Funds for the grants awarded to organisations by the Foundation for the realisation of civil society projects come from the County of Istria, the Fund of Cities and Municipalities, the Philanthropic Fund and the National Foundation for Civil Society Development

3. education - it organises workshops, panels, seminars and roundtables on topics related to civil society and issues important to all citizens.

It can be concluded that the main activities run by social enterprises can be categorised as those performed by civil society (pure non-profit ventures) and those hybrid ventures which are partially founded on the basis of the sale of products and services on the market and partially dependent on external funding and philanthropic donations. However, a pure for-profit social enterprise does not really exist and, in terms of new developments and new trends in general, the country itself should look for options on 
how to attract these kind of organisations and how to enable them to operate more efficiently on the market.

There are several initiatives towards enhancing sensibility and familiarising people with the importance of social entrepreneurship. The Croatian Association of Co-operatives recently organised an international conference on Workers and Social Co-operatives with the aim of opening up further discussions and stimulating creative potential to start running a social business, as well as to make the government more sensitive to the need strongly to support such initiatives. In March 2013, the best social enterprises received awards from the Ministry of Labour and Social Systems (of the Republic of Croatia). The Office for Co-operation with NGOs was founded by regulation in 1998, with the aim of carrying out expert work in the domain of the Croatian government with regard to creating the conditions for co-operation and partnership with the nongovernmental, non-profit sector, and especially with associations in the Republic of Croatia. The online magazine for social development Pomakonline is designed to enhance social business initiatives in Croatia.

In addition, Croatia is also in the process of creating a Strategy for Social Entrepreneurship. This document should provide a step forward as well as a more clear articulation of the legal requirements concerning the regulation of such businesses although, even now, there are grounds in several laws for engaging in forms of social entrepreneurship.

We would suggest that the following steps could be helpful in attracting people to form new ventures which will have a single end in itself - the creation of social value - and be sustainable in the long-run:

- speed up the processes of the development of the Strategy of Social Entrepreneurship which should clearly underline the steps that need to be taken in order to strengthen the market penetration of social enterprises

- government should provide special incentives for initiatives of such a kind - i.e. the formation of social enterprises - in terms of tax cuts and reductions, special subsidies, etc.

- government should deliver significant incentives and schemes to enable social entrepreneurs find and raise capital more easily and to reduce their reliance on grants

- develop real-life examples to shed light on critical obstacles and the success factors concerning current social enterprises to reveal the gaps and provide help where it is needed, as well as to channel the most critical issues to a place where they can potentially be resolved

- the transfer of knowledge through workshops, training schemes and conferences to make people acquainted with what social business is really all about

- government should develop a guide for people working in local and regional authorities on how social enterprises can help meet many of a local authority's strategic objectives. The guide should also give practical advice on how teams within local authorities can engage with social enterprises to benefit the communities they serve

- design a web portal under the auspices of the Ministry of Labour and Social Systems to provide advice and support for those on the journey of starting or growing a social enterprise 
- services offered from whichever source need to be better customised to suit the needs of the individual or the problem. This should be designed in harmony with all other surrounding systems, including those of the environment, society or people, with which social businesses interface

- provide advocacy for those who really aim to add value so as to speed up the process of gaining operating licences, etc.

- provide support for youth organisations through workshops, master classes and expert coaching sessions delivered by local or regional authorities and the government of the Republic of Croatia

- special focus should be placed on government to define projects that support social businesses by creating a list of proposed projects in order that they might both apply, in response to various calls for proposals by the European Commission in 2014 , and then use the money given for that purpose.

\section{Concluding remarks}

Social enterprises have primarily social objectives, in spite of their revenue-generating aims. Operating as traditional businesses, sometimes this makes it difficult to realise the differences between the two. However, looking more deeply, the mission of a social enterprise is to achieve social, cultural or community-based economic or environmental outcomes, apart from simply generating revenue. Entrepreneurial methods are always in use to accomplish the main goal for a better society. Consequently, the results are not calculated or measured in monetary terms but rather in terms of the numbers of jobs created for those marginalised from society, or for people with disabilities or those who have lost their employment status; the numbers of people who, as a result of their areas of activity, are no longer reliant on the social safety net; increases in the numbers of contributing taxpayers; increases in the numbers of people benefiting from environmentally-sensitive, or simply healthier, products and services; the amount of waste saved from going to landfill; etc.

Social enterprises create value and generate income which is reinvested; they provide innovative and unique solutions to social problems and are very beneficial to the poor; they offer flexible working environments and employ people with disabilities or people from specific workgroups, etc.

In this paper, the authors have presented the most popular social enterprises in the form of leveraged non-profit and hybrid non-profit organisations. These are currently virtually the only two models operating successfully in the economy, although the number of such enterprises is still very low.

In the Republic of Croatia, the lack of social businesses in the form of a pure forprofit organisational model is evident. A strong push needs to be given so as to attract more enthusiasts into starting a business in this direction. Bearing in mind the current conditions in the country, social business models do have to be supported to boost the economy in general and bring smiles to the faces of people as a sign of satisfaction.

The civil sector in Croatia has spawned a form of social enterprise that will surely find its own space in the economic sector. 


\section{References}

Austin, J, H. Stevenson and J. Wei-Skillern (2006) 'Social and commercial entrepreneurship: Same, different, or both?' Entrepreneurship Theory \& Practice 30: $1-22$.

Bacq, S and F. Janssen (2011) 'The multiple faces of social entrepreneurship: A review of definitional issues based on geographical and thematic criteria' Entrepreneurship \& Regional Development 23(5-6): 373-403.

Barringer, B. R and R. D. Ireland (2010) Entrepreneurship - successfully launching new ventures Boston: Pearson.

Battilana, D and S. Dorado (2010) 'Building sustainable hybrid organizations: The case of commercial microfinance organizations' Academy of Management Journal 53: 1419-1440.

Cho, A. H (2006) 'Politics, values and social entrepreneurship: A critical appraisal' in J. Mair, J. Robinson and K. Hockerts (Eds.) Social entrepreneurship Basingstoke, UK: Palgrave Macmillan, pp. 34-56.

Hartigan, P (2006) 'It's about people, not profits' Business Strategy Review 17(4): 42-45.

Haugh, H (2006) 'Social enterprise: Beyond economic outcomes and individual returns' in J. Mair, J. Robinson and K. Hockerts (Eds.) Social entrepreneurship Basingstoke, UK: Palgrave Macmillan.

Hockerts, K (2006) 'Entrepreneurial opportunity in social purpose business ventures' in J. Mair, J. Robinson and K. Hockerts (Eds.) Social entrepreneurship Basingstoke, UK: Palgrave Macmillan.

Korosec, R. L and E. M. Berman (2006) 'Municipal support for social entrepreneurship' Public Administration Review 66(3): 448-462.

Light, P. C (2006) 'Reshaping social entrepreneurship' Stanford Social Innovation Review Fall, pp. 46-51.

Mair, J and I. Martí (2006) 'Social entrepreneurship research: A source of explanation, prediction and delight' Journal of World Business 41(1): 36-44.

Martin, R. J and S. Osberg (2007) 'Social entrepreneurship: The case for a definition' Stanford Social Innovation Review Spring, pp. 29-39.

Masseti, B. L (2008) 'The social entrepreneurship matrix as a "tipping point" for economic change' $E: C O$ 10(3): 1-8.

Miller, T, M. G. Grimes, J. S. McMullen and T. J. Vogus (2012) 'Venturing for others with heart and head: How compassion encourages social entrepreneurship' Academy of Management Review 37(4): 616-640.

Roberts, D and C. Woods (2005) 'Changing the world on a shoestring: The concept of social entrepreneurship' University of Auckland Business Review Autumn, pp. 45-51. 
Tracey, P \& O. Jarvis (2007) 'Toward a theory of social venture franchising' Entrepreneurship Theory \& Practice 31(5): 667-685.

Yunus, M (2008) Creating a world without poverty: Social business and the future of capitalism New York: Public Affairs Books.

Zahra, S. E, E. Gedajlovic, D. O. Neubaum and J. M. Shulman (2009) 'A typology of social entrepreneurs: Motives, search processes and ethical challenges' Journal of Business Venturing 24(5): 519-532.

Ashoka - Innovators for the Public (2011)

https://www.ashoka.org/social entrepreneur [last accessed 22 April 2013].

Echo in Green (2012) http://www.echoinggreen.org/about/what-is-social-entrepreneurship [last accessed 22 April 2013].

Next Big What (2010) http://www.nextbigwhat.com/social-entrepreneurship-definition-and-examples-297/ [last accessed 22 April 2013].

Skoll Foundation (2013) http://www.skollfoundation.org/skoll-entrepreneurs/ [last accessed 22 April 2013].

Skoll World Forum (2013) http://skollworldforum.org/about/what-is-social-entrepreneurship/ [last accessed 22 April 2013].

Social Enterprise UK (2012) http://www.socialenterprise.org.uk/about [last accessed 27 April 2013].

Schwab Foundation for Social Entrepreneurship (2012) http://www.schwabfound.org/ content/what-social-entrepreneur [last accessed 22 April 2013].

Social Enterprise Alliance (2012) https://www.se-alliance.org/why [last accessed 27 April 2013].

Autonomous Centre - ACT Čakovec (2009) http://actnow.hr/ [last accessed 24 April 2013].

ACT Printlab (2007) http://www.printlab.hr/web/hr/ [last accessed 24 April 2013].

ACT Konto (2009) http://act-konto.hr/ [last accessed 24 April 2013].

Social Co-operative Humana Nova (2009) http://www.humananova.org/hr/home/ [last accessed 24 April 2013].

Rodin let d.o.o. - Roda Association (2004) http://www.roda.hr/ [last accessed 24 April 2013].

Association for Young People Alfa Albona (2012) http://alfa-albona.hr/ [last accessed 24 April 2013].

Zvono Association (2003) http://udrugazvono.hr/ [last accessed 24 April 2013]. 
Kamensko Association (2011) http://www.poslovni.hr/hrvatska/bivse-radnice-kamenskog-osnivaju-zadrugu-203610 and http://www.facebook.com/otvorenokamensko [both last accessed 24 April 2013].

Baranja Association (2006) http://www.udruzenje-baranja.hr/ [last accessed 24 April 2013].

AKD Mungos Ltd (2012) http://www.ogi.hr/files/publikacije/ogi/Trening osnove sp.pdf [last accessed 24 April 2013].

Agricultural Co-operative Vodnjan-Dignano (2008) http://www.pz-vodnjan.hr/ [last accessed 24 April 2013].

Co-operative of the Association Koka hrvatica (2010)

http://www.zadruge.hr/index.php?option=com content\&view=article\&id=356:osniva-se-zadruga-udruge-koke-hrvatice- $\&$ catid $=42$ :prenosimo-iz-medija \&Itemid $=87$ [last accessed 24 April 2013].

Social Service Co-operative Martinov plašt (2011) http://www.martinov-plast.hr/index.php/program-rada [last accessed 24 April 2013].

Co-operative on Energetics Island of Krk (2012) http://ezok.hr/ [last accessed 24 April 2013].

Social Association of Business Women Krug (2009) http://libela.org/page/udrugaposlovnih-zena-krug/ [last accessed 24 April 2013].

e.glas Rijeka (2013) http://www.eglas.hr/ [last accessed 24 April 2013].

Republic of Croatia Office for Co-operation with NGOs (2012)

http://www.uzuvrh.hr/page.aspx?pageID=73 [last accessed 27 April 2013].

Foundation for Partnership and Civil Society Development Istria (2010) http:// www.civilnodrustvo-istra.hr/index.php?id=183 [last accessed 27 April 2013].

Croatian Chamber of Commerce (2013) http://www.hgk.hr/kretanja [last accessed 28 April 2013]. 